\title{
PENGARUH PASTA GIGI MENGANDUNG XYLITOL TERHADAP PERTUMBUHAN Streptococcus mutans SEROTIPE E (IN VITRO)
}

\author{
Resti*, EI Auerkari**, AT Sarwono** $^{* *}$ \\ * Mahasiswi Fakultas Kedokteran Gigi Universitas Indonesia \\ **Departemen Biologi Oral Fakultas Kedokteran Gigi Universitas Indonesia
}

\section{Keywords: \\ Dentifrice; \\ Xylitol; \\ Streptococcus mutans; \\ Serotype E; \\ Antibacterial effect}

\begin{abstract}
Streptococcus mutans serotype E is a major bacterium causing caries, and widely present in dental plaque. Dentifrices containing xylitol have been shown to inhibit the growth of these mutans streptococci. The aim of the study was to identify the influence of dentifrice containing xylitol on $S$. mutans serotype E (in vitro). The 1:1 solution of dentifrice containing xylitol was diluted to the test concentrations of $100 \%, 10 \%, 1 \%, 0.1 \%, 0.01 \%$, and $0.001 \%$, in addition to positive and negative control groups. These solutions were examined in $S$. mutans serotype E test cultures by the diffusion method. The resulting inhibition zone was $2.16 \mathrm{~mm}$ at a concentration of $10 \%$, and $3.0 \mathrm{~mm}$ at a concentration of $100 \%$. Zero zone size was found at all other test concentrations, and a significant (Spearman) negative correlation was indicated between the concentration of dentifrice and the growth of mutans streptococci $(\mathrm{p}<0.05)$. The MIC was not been identified, but MBC was $10 \%$. In conclusion, the dentifrice containing xylitol can significantly inhibit the growth of $S$. mutans serotype $\mathrm{E}$ at least at dentrifice concentrations of 5-10\%.
\end{abstract}




\section{Pendahuluan}

Xylitol ialah pemanis alami nonkariogenik yang banyak ditemukan pada tanaman contohnya plum, strawbwrry, kembang kol, raspberry, serta serat kayu pohon birch yang banyak terdapat di Finlandia. ${ }^{1,2,3}$ Xylitol juga diproduksi di dalam tubuh manusia. ${ }^{3}$ Xylitol merupakan gula alkohol (polyols) yang mempunyai lima ikatan rantai karbon dengan rumus kimia $\mathrm{C}_{5} \mathrm{H}_{12} \mathrm{O}_{5}{ }^{1,4}$ Xylitol memiliki rasa semanis sukrosa dan memberikan efek segar di dalam mulut. ${ }^{2,5}$ Dalam kedokteran gigi, xylitol telah banyak diaplikasikan dalam berbagai macam produk seperti permen karet, tablet hisap, serta pasta gigi. ${ }^{6}$ Penelitian sebelumnya menyatakan bahwa xylitol sulit difermentasikan oleh Streptococcus mutans karena memiliki rantai karbon yang lebih pendek dibandingkan pemanis lainnya misalnya sorbitol. ${ }^{3,5}$

Streptococcus mutans diketahui sebagai mikroorganisme utama yang berperan dalam proses terjadinya karies gigi. ${ }^{7,8}$ Streptococcus mutans serotip E banyak ditemukan pada plak gigi manusia. Beberapa jenis karbohidrat seperti sukrosa dan glukosa dapat difermentasikan oleh Streptococcus mutans dan membentuk asam sehingga dapat menurunkan $\mathrm{pH}$ plak gigi. Penurunan $\mathrm{pH}$ yang berulang-ulang dalam waktu tertentu akan mengakibatkan terjadinya demineralisasi email sehingga proses karies dimulai. ${ }^{9}$

Masalah kesehatan gigi yang umum terjadi di masyarakat ialah karies gigi. Di Indonesia, karies gigi adalah penyakit endemik dengan derajat keparahan yang cukup tinggi. Menurut Survei Kesehatan Rumah Tangga (SKRT) Departemen Kesehatan RI tahun 2004, prevalensi karies gigi mencapai $90,05 \%$. $^{10,11}$ Oleh karena itu upaya pencegahan terhadap karies gigi sangat diperlukan. Salah satu caranya ialah dengan menggosok gigi menggunakan sikat gigi dan pasta gigi yang baik secara teratur dua kali sehari. ${ }^{12,13}$

Laporan penelitian terdahulu telah menyebutkan bahwa pasta gigi yang mengandung xylitol mampu menekan pertumbuhan bakteri penyebab karies yaitu Streptococcus mutans di dalam mulut. ${ }^{14}$
Sehingga sangat baik digunakan untuk orang yang memiliki resiko karies yang tinggi. Aplikasi pasta gigi mengandung xylitol ini juga merupakan salah satu langkah yang baik untuk pencegahan dini karies gigi di masyarakat. Hal inilah yang menjadi alasan penulis untuk meneliti lebih lanjut mengenai pengaruh pasta gigi mengandung xylitol terhadap pertumbuhan Streptococcus mutans yang banyak terdapat dalam plak gigi manusia yaitu Streptococcus mutans serotip E. Tujuan dari penelitian ini adalah untuk mengetahui bagaimana pengaruh variasi konsentrasi larutan pasta gigi mengandung xylitol terhadap pertumbuhan Streptococcus mutans serotip E.

\section{Bahan dan Cara Kerja}

Penelitian ini telah mendapatkan persetujuan dari Komisi Etik Fakultas Kedokteran Gigi Universitas Indonesia. Beberapa tahap penelitian dilakukan di dalam lemari kaca steril. Pasta gigi yang diujikan ialah pasta gigi yang mengandung xylitol merk Pepsodent yang diproduksi oleh Unilever Finland Oy, Helsinki.

Bakteri Streptococcus mutans standar strain serotip E murni yang telah tersedia di Laboratorium Biologi Mulut Fakultas Kedokteran Gigi Universitas Indonesia diperiksa dengan pewarnaan gram untuk mengetahui kemurniannya. Satu sengkelit bakteri Streptococcus mutans diambil dengan kawat inokulasi steril dan diletakkan pada kaca preparat yang telah diberi tanda lingkaran. Tuangkan cairan gentian violet pada gelas objek tersebut selama 3 menit, kemudian buang cairan tersebut dan tuangkan lugol pada kaca preparat. Bilas preparat dengan alkohol, kemudian tuangkan air fuchsin safranin sesaat lalu dibilas dengan air yang mengalir. Lihat koloni Streptococcus mutans serotip E pada gelas objek dengan menggunakan mikroskop pada perbesaran $1000 \mathrm{x}$ dengan bantuan minyak imersi.

Streptococcus mutans serotip E diremajakan dengan mengambil satu sengkelit bakteri dengan kawat inokulasi steril, lalu 
dimasukkan ke dalam tabung reaksi berisi cairan BHI. Spesimen tersebut kemudian dimasukkan ke dalam anaerobic jar, diberi gas pack, dan ditutup rapat. Kemudian disimpan pada suhu $37^{\circ} \mathrm{C}$ selama $3 \times 24$ jam.

Bakteri murni yang telah diremajakan kemudian di bandingkan tingkat kekeruhannnya dengan standar Mc Farland. Standar Mc Farland ini digunakan untuk menghitung jumlah koloni bakteri. Jumlah bakteri yang akan digunakan adalah $\pm 50 \mathrm{sel} / \mathrm{ml}$. Oleh karena itu, setelah disetarakan kekeruhannya dengan standar Mc Farland, bakteri diencerkan dengan larutan salin steril hingga jumlah bakteri yang ada dalam tabung reaksi mencapai $\pm 50 \mathrm{sel} / \mathrm{ml}$.

Pembuatan larutan pasta gigi xylitol

a. Pembuatan kelompok kontrol positif dan kontrol negatif

Untuk kelompok kontrol positif, masukkan $4.5 \mathrm{ml}$ perbenihan cair BHI ke dalam tabung reaksi. Sedangkan untuk kelompok kontrol negatif, timbang pasta gigi yang mengandung xylitol ke dalam botol kecil sebanyak 5 gram.
Ambil aquadest steril sebanyak $5 \mathrm{ml}$ dengan pipet pengencer eppendorf. Campurkan aquadest steril tersebut ke dalam botol berisi pasta gigi yang mengandung xylitol. Homogenisasikan dengan menggunakan vortex kemudian keseluruhan larutan diambil 4,5 ml. b. Serial pengenceran larutan pasta gigi xylitol

Untuk pembuatan konsentrasi $100 \%$, ambil pasta gigi yang mengandung xylitol ke dalam botol kecil sebanyak 5 gram, lalu campurkan aquadest steril sebanyak $5 \mathrm{ml}$ dengan pipet pengencer eppendorf. Homogenisasikan dengan menggunakan vortex. Untuk kelompok uji lainnya, masukkan ke dalam masing-masing lima tabung reaksi perbenihan cair BHI sebanyak $4.5 \mathrm{ml}$. Masukkan ke dalam tabung pertama larutan pasta gigi xylitol $100 \%$ sebanyak $0.5 \mathrm{ml}$. Vortex tabung tersebut agar larutan homogen, kemudian ambil larutan pada tabung pertama sebanyak $0.5 \mathrm{ml}$ dan masukkan ke tabung kedua. Lakukan hal yang sama hingga tabung ke lima.

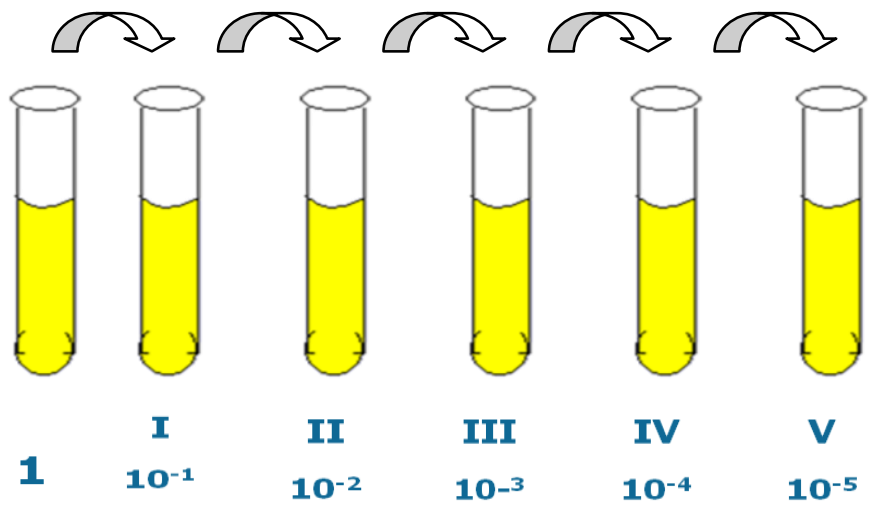

$\begin{array}{lll}\text { Keterangan: } & 1 & : 100 \% \\ & 10^{-1} & : 10 \% \\ & 10^{-2} & : 1 \% \\ & 10^{-3} & : 0,1 \% \\ & 10^{-4} & : 0,01 \% \\ & 10^{-5} & : 0,001 \%\end{array}$

Gambar 1. Skema pembuatan larutan 
Tes Sensitivitas Bakteri Terhadap Xylitol dengan Menggunakan Metode Difusi (Disk pada Agar DST) ${ }^{15,16}$

Tuang $1 \mathrm{ml}$ bakteri secara perlahan dan merata ke perbenihan agar DST pada Petri disk, lalu dimiringkan untuk dibuang kelebihannya. Perbenihan agar kemudian dieram dalam inkubator pada suhu $37^{\circ} \mathrm{C}$ selama 15 menit. Teteskan masing-masing larutan xylitol pada blank disk yang telah diletakkan di permukaan agar DST. Inkubasikan Petri disk tersebut dalam anaerobic jar pada suhu $37^{\circ} \mathrm{C}$ selama $3 \times 24$ jam. Setelah inkubasi selama 3 hari, hitung daya hambat larutan xylitol terhadap Streptococcus mutans serotip $\mathrm{E}$ dengan mengukur jari-jari zona hambat yang terdapat pada perbenihan agar DST tersebut. Supaya terbukti validitasnya, pengukuran dilakukan tiga kali.

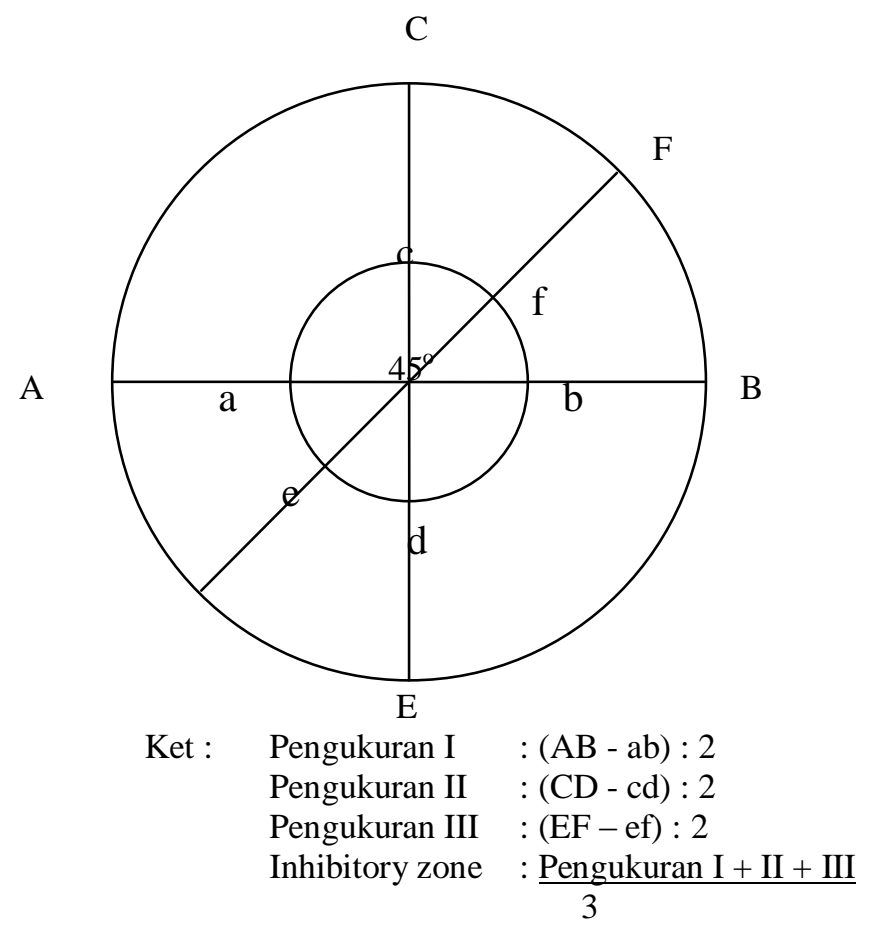

Gambar 2. Cara pengukuran zona hambat

Tes Sensitivitas Bakteri Terhadap Xylitol dengan Menggunakan Metode Dilusi ${ }^{15,16}$

Bakteri yang telah berjumlah $\pm 50 \mathrm{sel} / \mathrm{ml}$ dituang ke dalam tabung yang telah berisi larutan xylitol konsentrasi $100 \%, 10 \%, 1 \%$, $0,1 \%, 0,01 \%$, dan $0,001 \%$ serta kelompok kontrol baik positif maupun negatif. Masingmasing tabung dimasukkan bakteri sebanyak 0.5 ml. Kemudian masukkan tabung-tabung reaksi tersebut ke dalam anaerobic jar bersama gas pack selama $3 \times 24$ jam pada suhu $37^{\circ} \mathrm{C}$. Setelah inkubasi selesai, amati tingkat kekeruhannya.

Untuk menguji apakah larutan xylitol tersebut dapat membunuh bakteri Streptococcus mutans serotip E dilakukanlah tes gores pada media agar. Konsentrasi larutan xylitol yang tingkat kekeruhannya rendah (jernih) pada masing-masing spesimen Streptococcus mutans serotip E diambil satu sengkelit dengan kawat inokulasi steril kemudian digoreskan ke permukaan agar pada perbenihan TYS 20B. Setelah itu diinkubasikan dalam anaerobic jar selama 3 x 24 jam pada suhu $37^{\circ} \mathrm{C}$. Setelah $3 \times$ 24 jam perhatikan pertumbuhan bakteri Streptococcus mutans serotip E pada agar. Apabila terdapat pertumbuhan bakteri, maka konsentrasi tersebut merupakan Kadar Hambat Minimal (KHM), sedangkan jika tidak ada sama sekali pertumbuhan bakteri Streptococcus mutans serotip E pada agar tersebut, maka 
konsentrasi tersebut adalah Kadar Bunuh Hasil Minimum (KBM).

Data-data yang diperoleh kemudian dianalisis dengan uji stastistik deskriptif dan analitik yang sesuai.

Penelitian diawali dengan uji sensitivitas dengan metode difusi yang dilakukan dengan pengukuran zona hambat terhadap pertumbuhan Streptococcus mutans serotip E. Hasil uji sensitivitas dengan pengukuran zona hambat yang dilakukan dapat dilihat pada tabel 1 dan gambar 3.

Tabel 1. Hasil uji sensitivitas larutan pasta gigi yang mengandung xylitol terhadap Streptococcus mutans serotip E melalui metode difusi

\begin{tabular}{cll}
\hline No. & Konsentrasi $(\%)$ & Zona hambat rata-rata $(\mathbf{m m})$ \\
\hline 1. & 100,0 & 3,00 \\
2. & 10,00 & 2,16 \\
3. & 1,000 & 0,00 \\
4. & 0,100 & 0,00 \\
5. & 0,010 & 0,00 \\
6. & 0,001 & 0,00 \\
\hline
\end{tabular}

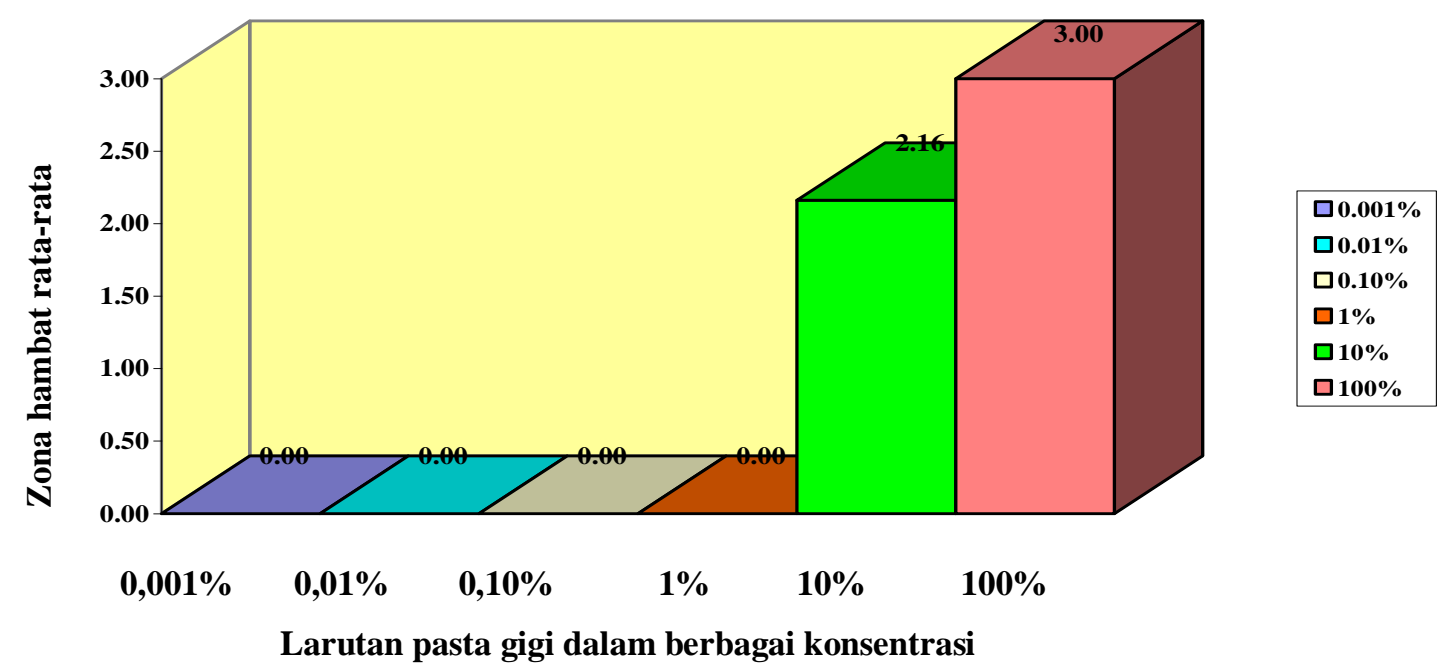

Gambar 3. Zona hambat rata-rata $(\mathrm{mm})$ berbagai konsentrasi larutan pasta gigi mengandung xylitol terhadap pertumbuhan Streptococcus mutans serotip E

Berdasarkan tabel 1 dan gambar 3 dapat dilihat bahwa pada pengenceran larutan pasta gigi yang mengandung xylitol dengan konsentrasi $0,001 \%, 0,01 \%$ dan $0,1 \%$ tidak terbentuk zona hambat terhadap Streptococcus mutans serotip E, sedangkan pada konsentrasi $10 \%$ mulai terbentuk zona hambat sebesar $2,16 \mathrm{~mm}$. Begitu pula pada konsentrasi $100 \%$ zona hambat yang terbentuk sebesar 3,00 $\mathrm{mm}$.
Data-data yang dihasilkan pada metode difusi kemudian dianalisis dengan uji analisis statistik parametrik yang salah satu persyaratannya adalah distribusi data yang normal. Oleh karena itu diuji dengan uji normalitas Shapiro-Wilk karena sample yang digunakan kecil dan didapatkan $\mathrm{p}=0,006$ berarti $\mathbf{p}<\mathbf{0 , 0 5}$ artinya distribusi data tidak normal. 
Selanjutnya dilakukan transformasi data untuk menormalkan data yang sebarannya tidak normal dengan sqrt (akar kuadrat), yang kemudian dilakukan uji normalitas untuk kedua kalinya. Hasil yang didapat $\mathrm{p}=0,003$ artinya distribusi data tidak normal.

Berdasarkan hasil uji normalitas yang menunjukkan bahwa distribusi data tidak normal walaupun telah dilakukan transformasi data, maka untuk mengetahui adanya pengaruh pasta gigi yang mengandung xylitol terhadap Streptococcus mutans serotip E dilakukan analisis statistik menggunakan uji Spearman (non parametrik) dengan $(\mathrm{p}<0,05)$. Data dianalisis dalam bentuk kategorikal yang hasilnya menunjukkan bahwa korelasi antar skor konsentrasi (\%) dan skor zona hambat (mm) adalah bermakna. Sig=0,042 ( $\mathrm{p}<0,05)$. Nilai korelasi sebesar $0,828 \rightarrow$ menunjukkan korelasi positif dengan kekuatan korelasi yang sangat kuat. $(0,80-1,00){ }^{17}$

Arah korelasi + (positif) yakni searah. Artinya semakin besar konsentrasi semakin besar pula zona hambat yang terbentuk. ${ }^{17}$

Untuk memastikan hasil penelitian dengan metode difusi, maka dilakukan penelitian lebih lanjut dengan metode dilusi melalui pengukuran tingkat kekeruhan, akan tetapi karena pasta gigi yang digunakan sebagai bahan penelitian telah memberikan warna yang cukup pekat maka tingkat kekeruhan tidak dapat diukur. Kemudian penelitian dilanjutkan dengan tes gores pada media agar, hasilnya ditunjukkan pada Tabel 3.

Tabel 3. Hasil tes gores

\begin{tabular}{ccccccccc}
\hline Tes Gores & \multicolumn{6}{c}{ Konsentrasi Larutan Pasta Gigi Yang Mengandung Xylitol } \\
\cline { 2 - 8 } S. mutans & $100 \%$ & $10 \%$ & $1 \%$ & $0,1 \%$ & $0,01 \%$ & $0,001 \%$ & Kontrol (+) & Kontrol (-) \\
\hline Serotip E & - & - & + & + & + & + & + & - \\
& & & & & & & \\
Keterangan: & + & = ada pertumbuhan bakteri & & & \\
& - & = tidak ada pertumbuhan bakteri
\end{tabular}

Dari tabel 3 terlihat bahwa hanya pada larutan dengan konsentrasi $10 \%$ dan $100 \%$ menunjukan hasil negatif (-) yang berarti tidak terdapat pertumbuhan bakteri pada Streptococcus mutans serotip E. Sedangkan pada kelompok kontrol menunjukkan bahwa terdapat pertumbuhan Streptococcus mutans pada kontrol positif dan tidak terdapat pertumbuhan Streptococcus mutans pada kelompok kontrol negatif.

\section{Pembahasan}

Penelitian ini dilakukan untuk mengetahui pengaruh pasta gigi mengandung xylitol terhadap pertumbuhan Streptococcus mutans serotip E secara in vitro. Pada penelitian ini, pasta gigi mengandung xylitol dipilih karena merupakan hal yang relatif masih baru di
Indonesia, bahkan saat penelitian ini selesai dilakukan belum terdapat pasta gigi mengandung xylitol yang telah beredar di Indonesia. Bakteri Streptococcus mutans serotip E dipilih sebagai objek penelitian karena bakteri tersebut dilaporkan banyak ditemukan pada plak gigi manusia dan juga merupakan agen penyebab karies gigi. ${ }^{18}$ Di beberapa negara pasta gigi mengandung xylitol ini telah direkomendasikan penggunaannya karena terbukti efektif menurunkan karies. ${ }^{19}$ Namun belum terdapat penelitian lebih lanjut tentang seberapa besar pengaruhnya terhadap pertumbuhan Streptococcus mutans serotip E. Dengan demikian penelitian ini dimaksudkan untuk mengetahui seberapa besar pengaruh pasta gigi mengandung xylitol terhadap pertumbuhan Streptococcus mutans serotip E dan hubungannya dalam berbagai konsentrasi dari pasta gigi yang diujikan. 

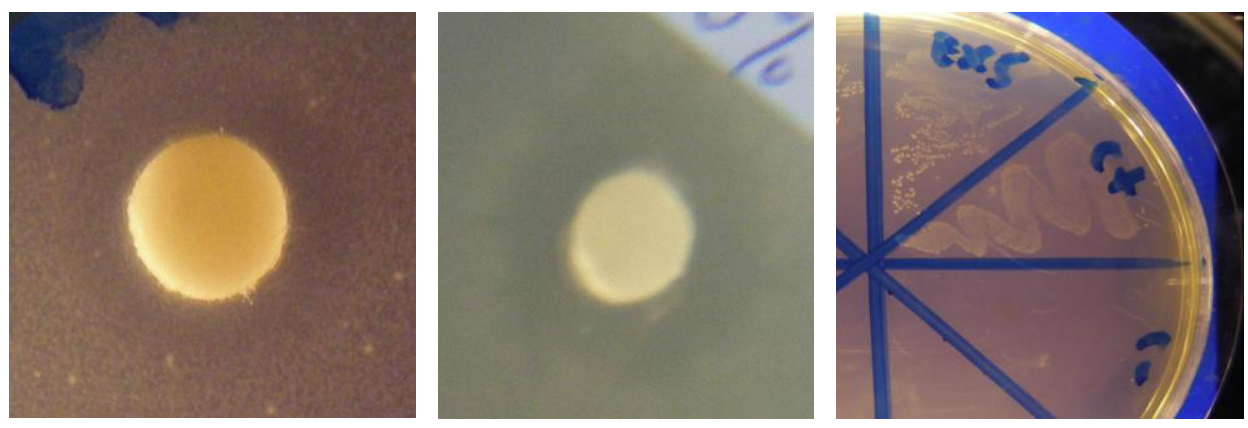

Gambar 4. Beberapa zona hambat dan tes gores yang terbentuk

Berdasarkan hasil penelitian yang dilakukan dengan metode difusi (tabel 1 dan gambar 3), dapat diketahui bahwa zona hambat mulai terbentuk pada konsentrasi $10 \%$ dari pertumbuhan Streptococcus mutans serotip E. Zona hambat juga terbentuk pada konsentrasi $100 \%$. Hal ini sejalan dengan penelitian terdahulu yang menyatakan bahwa pasta gigi mengandung xylitol mampu menghambat pertumbuhan Streptococcus mutans, yang ditandai dengan terbentuknya zona hambat. ${ }^{20}$ Setelah dilakukan analisis dengan menggunakan uji non parametrik Spearman yang hasilnya dapat dilihat pada tabel 2. Terdapat perbedaan yang bermakna pada pertumbuhan Streptococcus mutans serotip E $(\mathrm{p}<0,05)$. Hal ini menunjukkan bahwa pasta gigi mengandung xylitol dapat mempengaruhi pertumbuhan Streptococcus mutans serotip E, dengan derajat kemaknaan adalah 0,042.

Dengan arah korelasinya adalah + (positif) atau searah, yang artinya semakin besar konsentrasi pasta gigi mengandung xylitol, maka semakin besar pula zona hambat yang terbentuk.

Untuk memastikan hasil penelitian dengan metode difusi, maka dilakukan penelitian melalui pengukuran tingkat kekeruhan dan tes gores. Namun pada penelitian ini tingkat kekeruhan tidak dapat diukur karena pasta gigi yang digunakan sebagai bahan penelitian memiliki warna yang cukup pekat, sehingga menimbulkan kekeruhan tersendiri, diluar dari warna keruh yang menunjukkan adanya pertumbuhan Streptococcus mutans.
Oleh karena itu untuk mengujinya, dilakukan tes gores pada media agar pada semua konsentrasi. Hasilnya dapat dilihat pada tabel 3. Dimana pada konsentrasi $1 \%-0,001 \%$ masih terdapat pertumbuhan Streptococcus mutans serotip E. Sedangkan pada konsentrasi $10 \%$ dan $100 \%$ tidak terdapat pertumbuhan bakteri. Hal ini menunjukkan bahwa konsentrasi $10 \%$ dari volume pasta gigi merupakan nilai KBM pasta gigi mengandung xylitol terhadap Streptococcus mutans serotip E. Apabila pada penelitian ini diasumsikan kandungan xylitol yang terdapat dipasta gigi adalah 5-10\%, maka nilai KBM adalah $0,5-1 \%$ volume xylitol. Nilai $\mathrm{KBM}$ ini sesuai dengan penelitian terdahulu yang menyatakan bahwa KBM pasta gigi yang mengandung xylitol terdapat di konsentrasi $10 \%$ volume pasta gigi. ${ }^{20}$

Sedangkan nilai KHM belum dapat ditentukan pada penelitian ini karena pada seluruh konsentrasi dibawah $10 \%$, selain terdapat pertumbuhan bakteri pada metode dilusi dengan menggunakan tes gores, tidak terbentuk pula zona hambat dalam metode difusi. Hal ini menunjukkan nilai KHM mungkin terdapat pada konsentrasi antara 1 $10 \%$ volume pasta gigi. Di lain pihak, penelitian terdahulu menyatakan bahwa nilai KHM ada pada konsentrasi $1 \%$ volume pasta gigi. $^{20}$ Perbedaan ini diduga disebabkan oleh perbedaan merk pasta gigi yang diteliti beserta kandungan pasta didalamnya. Oleh karena itu perlu dilakukan penelitian lebih lanjut dengan menggunakan konsentrasi yang berbeda sehingga dapat diketahui dengan jelas nilai 
KHM dari pasta gigi mengandung xylitol tersebut.

Penelitian ini menyatakan bahwa pasta gigi mengandung xylitol yang diuji mempunyai pengaruh terhadap pertumbuhan Streptococcus mutans serotip E secara in vitro. Pengaruhnya berupa efek antibakteri dari pasta tersebut serta dapat terhambatnya pertumbuhan Streptococcus mutans serotip E.

\section{Kesimpulan}

Pasta gigi mengandung xylitol dapat menghambat serta mempunyai efek anti bakteri terhadap pertumbuhan Streptococcus mutans serotip E. Semakin tinggi konsentrasi pasta gigi mengandung xylitol maka semakin besar zona hambat yang terbentuk pada pertumbuhan Streptococcus mutans serotip E.

\section{Daftar Acuan}

1. Newburn E. Cariology. $3^{\text {rd }}$ ed. San Fransisco: Quintesence Publishing Co Inc, 1989: 135-68, 295-309, 273-89.

2. Nizel AE \& Papas AS. Nutrition in Clinical Dentistry. $3^{\text {rd }}$ ed. Philadelphia: WB Saunders Company, 1989: 23.

3. Makinen KK. The Chemical Profile of Xylitol; Terminology. Basel: Birkhauser Verlag, 1978.

4. Vadeboncoeur C, Trahan L, Mouton C, Mayrand D. Effect of Xylitol on the Growth and Glycolysis of Acidogenic Oral Bacteria. J Dent Res 1983; 62(8):882-4.

5. Kakuta H, Iwami Y, Mayanagi H, Takahashi N. Xylitol Inhibition of Acid Production and Growth of Mutans Streptococci in the Presence of Various Dietary Sugars under Strictly A naerobic Conditions. Caries Res 2003; 37:404-9.

6. Holgerson PL, Blicks CS, Sjostrom, Oberg M, Twetman S. Xylitol Concentration in Saliva and Dental Plaque after Use of Various XylitolContaining Products. Caries Res 2006; 40: 3937.
7. Mangundjaja S, Muthalib A, Djais A, Auerkari El. The Effect of Chlorhexidine Mouthwash Treatment on Salivary Mutans Sterptocomal Levels in Orthodontic Patients. JKGUI 2000; 7(Edisi Khusus): 55-9.

8. Schuster GS, Wesley G. Oral Microbiology and Infectious Diseases. $2^{\text {nd }}$ ed. Baltimore: Williams \& Wilkins, 1983: 47-56, 197-231.

9. Fejerskov O, Kidd EAM. Dental Caries The Disease and Its Clinical Management. Oxford: Blackwell Publishing Company, 2003.

10. Kompas.http:// www.kompas.com/ver1/Kesehatan/0708/27/115734.html. 14/10/2007.

11. Litbang.http://surkesnas.litbang.depkes.go.id/ind ex2.php?option $=$ com content\&do $\_$dff $=1 \&$ id $=4$ 6.29. 12/04/2007.

12. Harris NO \& Franklin GG. Primary Preventive Dentistry. $5^{\text {th }}$ ed. Stamford: Appleton \& Lange, 1999: 41-57.

13. Roth GI, Calmes R. Oral Biology. Missouri: CV Mosby Company, 1981: 436-50.

14. Mangundjaja S, Sutadi H, Andika DK. Effectiveness of Dentifrice Containing Xylitol on Salivary mutans streptococci. FDI Annual World Dental Congress Malaysia 2001. (Abstract).

15. Jawetz E, Melnick JL, Adelberg EA. Medical Microbiology. $19^{\text {th }}$ ed. California: Appleton \& Lange, 1991.

16. Koneman EW, Allen SD, Dowell VR, Janda WM, Sommers HM, Winn WC. Color Atlas and Textbook of Diagnostic Microbiology. $3^{\text {rd }}$ ed. Philadelphia: JB Lippincott Company, 1988: 487-99.

17. Dahlan S. Statistik untuk Kedokteran dan Kesehatan. Jakarta: PT Arkans, 2004: 48-64, 164-73.

18. Samaranayake LP. Essential Microbiology for Dentistry. $\quad 2^{\text {nd }}$ ed. Hongkong: Churchill Livingstone, 2002: 38-52, 95-8.

19. Peldyak J, Bybee LW, Johnson E, Misner LR. Practical Application of Xylitol in Dentistry. Finnish Dent J 2006; 1: 54-61.

20. Auerkari EI, Mangundjaja S. Antimicrobial Activity of Xylitol Containing Dentifrice on Mutans Streptococci. IADR Congress Bali 2007. 